\title{
Effect of Training on the Performance of University Administrative staff in Nigeria
}

\author{
Modupe Olayinka Ajayi ${ }^{1}$, Omonigho Tonia Okhankhuele ${ }^{2}$ \\ ${ }^{1}$ Department of Project Management Technology, Federal University of Technology, Akure, Nigeria. Tel: 08034016340. \\ Email:modupe_ajayi@futa.edu.ng \\ ${ }^{2}$ Department of Business Administration, Federal University of Technology, Akure, Nigeria. Tel: 08062824074. \\ Email:omotonia2013@gmail.com or otokhankbuele@futa.edu.ng
}

\begin{abstract}
Several studies have been carried on the effect of training on employees' performance in firms. However, the effect of training on the performance of universities' administrative staff in Nigeria has not been adequately assessed. This paper identified the training types mostly used by the Administrative staff of The Federal University of Technology Akure (FUTA), Ondo State, Nigeria, examined the factors affecting effective training and assessed the effect of training on the performance of the staff. The paper sought answers to research questions by employing survey design and purposive sampling technique to collect data from 68 respondents with the help of a 17-item structured questionnaire. The respondents consisted of the administrative staff of FUTA. Data for this study were analyzed using descriptive statistics such as percentage, mean score, standard deviation, mean ranking, and chi-square was used to test the hypothesis posed for the research at $5 \%$ significant level. Reliability test was carried out with Cronbach Alpha, while the validation of the research instrument was carried out by a senior lecturer in the Department of Business Administration, FUTA. The study revealed that training (On the Job and Off the Job) had a significant effect on the respondents' performance; however, management did not release enough funds towards adequate training of the administrative staff. The paper, therefore, recommended more investment in training the staff in current skills and methods in order to cope with frequent changes in this contemporary world.
\end{abstract}

Keywords: Training, Employees' training, Performance, Employees' performance.

Citation: Modupe Olayinka Ajayi, Omonigho Tonia Okhankhuele. Effect of Training on the Performance of University Administrative staff in Nigeria, 2019; 4(1): 1-22.

Received: January 3, 2018

Accepted: April 25, 2019 


\subsection{Introduction}

\subsection{Background}

The competitiveness in the current business world and the fast pace global and technological advancement being faced by firms pose a lot of difficulties and demand high-quality human resource and highly trained labour force for firms to succeed. Employees endowed with great knowledge, high innovative skills and experience are now required to withstand the daily challenges being encountered by employees at their workplaces. Realizing this, organizations in the globe now invest in employee training and education with a view to improving the quality of employees' work (Nel et al., 2004; Naveed et al., 2014). In consequence, workers have become vital assets of every organization. Being vital assets, it is necessary for them to be treated as human capital. A huge sum of capital is being invested incessantly in developing their capabilities and keeping them up to date with current information, knowledge, skills and aptitude necessary to perform their duties and create a competitive advantage for their firms. Their boosted behaviour and skills make their organizations to have a competitive edge (Kum et al., 2014).

Training is a formal and systematic modification of behaviour through learning by means of instruction, education, premeditated experience and development (Armstrong, 2000). It is "a planned effort to facilitate the learning of job-related knowledge, skills, and behaviour by employees" (Noe et al. 2003) and "the planned intervention that is designed to enhance the determinants of individual job performance" (Chiaburu and Tekleab, 2005). It involves a systematic achievement of concepts or rules, attitude, and skills that result in the enhancement of job performance (Goldstein, 1993). Employees' training provides them with improved skills, professional advancement opportunities and novel behaviour which enhance their performance (Amin et al., 2013; Elnagal and Imran, 2013). These skills help them to be more productive and

efficient in carrying out their jobs (Thomas, 1997; Onyango, and Wanyoike, 2014) and prepare them to carry out more compound jobs (Onyango, and Wanyoike, 2014). Trained human resources are key to upholding a company's competitive advantage (Schonewille, 2001). Training helps to furnish employees with specific skills or correct the deficiencies in their performance (Reed and Vakola, 2006). Therefore, training is effected when skill inadequacy is detected in a worker or when an organization makes some changes in its system and requires employees to obtain new skills to be able to adapt to these changes (Roberson, Culik, and Pepper, 2001). 
Junevicius and Seniunaite (2007) are of the opinion that performance is generally linked with popular "3 E" (economy, efficiency and effectiveness). They referred to 'performance' as the relationship between minimal and effective cost ("economy"), between effective cost and output attained ("efficiency") and between input and outcome achieved ("effectiveness). Effectiveness can be measured by comparing actual performance outcomes with some set standards against which employees' performance is measured. Several authors have carried out researches on the effect of training on employees' performance and they have come out with diverse conclusions. While Oribabor (2000), Jagero et al., 2012, Elnaga1 and Imran (2013), Kum et al. (2014), Onyango and Wanyoike (2014) among others concluded that, employees' training is essential to continuously upgrade their knowledge and skills in preparedness to cope with the ever-changing competitive business world, other scholars (Ginsberg, 1997; Robbins et al., 2003) see employees' training as an expense and the responsibility of the school system to train them on their various expertise. Hence employees' training is a waste of an organization's capital. The main objective of this study, therefore, is to evaluate the effect of training on employees' performance using the administrative staff of The Federal University of Technology Akure (FUTA), Ondo State, Nigeria, as a case study. The theory underpinning this study is Armstrong (2009) framework for systematic training in an organization. This framework is appropriate for this study because it clarified how training improves employees' performance and leads to increased organisational performance.

\subsection{Empirical Literature}

Onyango and Wanyoike (2014) stated that training is mainly imparted in two ways: These include: On the job training which is made available to employees within their daily working environment and off the job training method which is made available to employees outside their working environment, for example, conferences, seminars, workshops, among others. Elnaga and Imran (2013) disclosed that training could be imparted via diverse methods such as peers' cooperation, coaching and mentoring and participation by the subordinates. On the other hand, Banjoko (1996) opined that there are three major types of training and development methods. These methods include: On the job training method, off the job training method and simulation. He further cited some examples of each of these training methods as shown in table 1 below.

Table 1: Types of Training and Development Methods

\begin{tabular}{lll}
\hline On the Job Method & Off the Job Method & Simulation \\
\hline Job Rotation & Classroom Lectures & Case Studies \\
\hline
\end{tabular}




$\begin{array}{lll}\text { Internship } & \text { Film Show and Demonstration } & \text { Business Games } \\ \text { Apprenticeship } & \text { Vestibule Training } & \text { Critical Incidence } \\ \text { Coaching } & \text { Role Playing } & \text { Role Playing } \\ \text { Committee Assignment } & \text { Educational Television } & \text { In Basket } \\ \text { Task Force Assignment } & \text { Programme Instruction } & \end{array}$

Source: Banjoko (1996)

In agreement with Onyango and Wanyoike (2014), Flynn et al. (1995) affirmed that on the job training decreases cost and saves time. While Afaq and Khan (2008) asserted that employees who have more on the job experience perform better since this experience assists them in attaining an upturn in both capabilities and skills. On the job training assists employees to gain knowledge of and comprehend their jobs in a better mode (Deming, 1982).

Katcher and Snyder (2003) stated that it is necessary for employees to be trained because training increases their ability to adapt to change; trained employees have more ability to use up-to-date equipment optimally and therefore upturn their productivity. Hence, when employees' skills are upgraded it contributes to full personal advancement of the employees and the socio-economic improvement of the nation at large. On the other hand, Rothwell and Kazanas (2006) categorized the reasons for training as (i) to fill a "performance gap" discovered in the course of performance management process; and (ii) to fill up a "growth gap", that is, an open position in an organization. Elnaga1 and Imran (2013) summed it up by saying that the overall benefits attained from employee's training include: increased motivation, reduced employee turnover, increased job satisfaction and morale, increased financial gain, increased capability to adopt novel technologies and methods, increased efficiencies in processes and increased innovation in strategies and products.

\subsubsection{Factors that affect Training and Development in an Organization}

Kum et al., (2014) identified working conditions and insufficient resources as factors that affect training and development of employees, while Kreitner and Kinicki (2007), opined that there are some factors on the job that avert the transfer of learning. These factors include: (i) When learners do not see any value in applying new skills, do not believe that they will receive rewards from learnt skills, do not value the rewards that will be attained from learning such skills nor do they believe that transfer of learning from the classroom to the job will take place; (ii) When individuals have little or no freedom to change what they do because of tight control over their job tasks, then the knowledge and skills derived from training can never be put to 
use unless the task controls are unstiffened; (iii) When the supervisor of a learner is not in favour of training, then there is little or no possibility that a learner will be making use of newly learnt skills, because supervisors exert great influence over their subordinates' behaviour, since they control rewards and punishment; (iv) When a trainee comes back to his project field to discover that his coworkers are sceptical at receiving new ideas, training will not be effectively conveyed. Also, many employers see training as an expense (Ginsberg, 1997; Robbins et al., 2003), as the responsibility of employers, which is difficult to convince shareholders to approve. Therefore, employers feel that the responsibility to train employees falls on the school system, not on firms. Thus, training is the duty of the employees, to learn how to do their jobs (Robbins et al., 2003). Similarly, Ginsberg (1997) perceived training as expensive. He, however, stated that effective training can save money for an organization through efficiency. While Flynn et al., (1995) opined that though it is expensive to train employees, in the long run, training gives recoups for organizations more than it takes.

Cascio (2005) on the other hand, itemized other factors that affect training. These factors include: (i) Unavailability of adequate funds which may not be budgeted for by firms, can thwart employees' training and development. (ii) Employees now have less job security which makes employees continually search for employers who will make available to them, opportunities to develop transportable skills; (iii) A lot of organizations have a flat organizational structure which leaves little room for promotion. This limits the opportunities for training and developing employees. Meanwhile, Perry (2007) and Kleiman (2003), asserted that the failures of training and development programmes are linked to some reasons. Firstly, when training objectives are not affiliated with the business needs. Secondly, when the source of the problem of poor performance is related to factors such as the job design, motivation and reward systems, which are unrelated to training. Then training will be worthless. Thirdly, when there is an absence of objectives to make available focus and direction, training will surely not thrive.

Researchers also admitted that if training is too costly when compared to its short-term return on investment, firms may perceive it to be a failure and unacceptable. Nonetheless, the long-term pay-off may be rewarding (Kum et al., 2014). Each time training is seen as a sole event, the likelihood of behaviour change is little, and training is moreover probable to fail if partakers in the training are not held answerable and responsible for the results (Kleiman, 2003; Kum et al., 2014). Usually, employees are not held answerable to the use of the contents of their training at their places of work. Also, the training efforts will be in vain if it is not supported by line management. Failure by direct supervisors or managers to support the training of their subordinates will result in the employees resisting applying the new knowledge and 
skills attained during their training programme. The commitment of top executive is also crucial for a training programme to be successful because top management will need to apportion resources and participate in designing the process of the training. Furthermore, training and development will be unsuccessful if feedback is not provided. When firms fail to assess training by making feedback unavailable, employees will be unable to assess their progress and the organizers will not be able to know the extent of success of their programmes (Kum et al., 2014). Also, if after training employees fail to transfer what they have learnt to their working environment, in order to improve performance, the training will be valueless (Kum et al., 2014).

\subsubsection{Effect of Training on Employees' Performance}

Becker (1975), Peteraf (1993), Bartel (1994), Analoui (1994), Delery and Doty, (1996), Guest (1997), Wright and Geroy (2001), Obisi (2001), Dola (2011), Jagero et al. (2012), Elnaga1 and Imran, 2013, Falola et al. (2014, Naveed et al. (2014), Kum et al. (2014), Noor and Usman (2014), Falola et al., (2014), Onyango, and Wanyoike, (2014) among others agreed that training has a lot of positive effect on the quality of the workers' competence, skills, knowledge, loyalty and attitude necessary for the employees to perform future jobs. Consequently, it results in greater employees' performance, organizational productivity and creates competitive advantage. Training makes available to employees, skills that increase their performance (Kum et al., 2014). When employees' training is effective, employees possibly make fewer mistakes which can lead to an improvement in the quality of goods they produce and the services they render. Rothwell and Kazanas (2006) affirmed that training does not only have influence on outcome, but it is also essential for saving cost. There are findings that trained employees are more proficient in executing different tasks (Jagero et al., 2012). Training of employees inspires growth within the employees and the entire organization (Katcher and Snyder, 2003). Armstrong (2000) affirmed that employees who are trained usually work better as teams since they are all cognizant of expectations from them, therefore, they can attain these expectations smoothly together. Employees who receive consistent training are more inclined towards accepting change and coming up with novel ideas. Also, employees who go through appropriate training have the tendency to keep their jobs longer than those who do not (Elnaga1 and Imran, 2013).

Employees' training programs serve as a solution to covering performance issues like filling the gap between set standard and actual performance (Swart et al., 2005). Training may help employees to reduce their anxiety or frustration, occasioned by work demands, which they are not conversant with, and are 
deficient in the skills required to handle them effectively (Chen et al., 2004). Training has a direct relationship with employees' performance (Armstrong, 2000; Naveed et al., 2014, Harrison (2000). There is a positive correlation between effective training program and employee's productivity (Bartel, 1994). Nkosi (2015) carried out a study on the "Effects of Training on Employee Commitment, Retention and Performance: A Case Study of a Local Municipality in South Africa”. The findings revealed that training has a significant effect on employees' commitment, performance enhancement and retention within the local municipality examined. Oguntimehin (2001) stated that training improves understanding and attitude; quality of work; productivity; skills; use of tools and machine; cuts down waste and other overhead costs; reduces lateness, labour turnover, accidents and absenteeism; gets rid of obsolesce in products, technologies, skills, methods, among others. However, Usman (2014) asserted that investment in training and development of staff can be a loss for a firm if it is not strategically planned, implemented and evaluated, meaning it will not improve the firm's performance.

\subsection{Methodology}

\subsection{Study Area}

Established in 1981, The Federal University of Technology, Akure, Ondo State, Nigeria, is made up of Academic and Administrative staff. The Registrar is responsible for the supervision and management of all administrative and operational functions. Under the supervision of the Registrar, the administrative staff carries out the function of ensuring the safety and accuracy of all academic records of students; expediting students' admission, matriculation, registration, data keeping, classroom allocation, examination timetable, degree verification, preparation of transcripts, convocation ceremonies, counselling of students and staff on academic matters, development and application of academic policies, management of scholarships and awards, among others. They also aid the Academic staff to facilitate several Academic functions and serve in various committees. The Administrative function comprises six divisions (Directorate of Establishment and Human Resource (DHR), Directorate of Academic Affairs, Council, Registrar's Office, Student Affairs Office and School Admin). These divisions consist of fifteen units (Training Unit, Welfare Unit, Junior Staff Training Unit, Academic Unit, Admin and Professional Staff Unit, Senate, Admission, Examination and Records, Council Affairs Unit, General Admin, Registrar's Office Officers, Student Affairs Office, Counselling Unit, School Officers and Admin Officers).

\subsection{Method}

The survey design was used for this study. A 17-item structured questionnaire was used to elicit information from the administrative staff (Total population, 91) of The Federal University of Technology 
Akure, Ondo State, Nigeria. The administrative staff of the university were purposively selected because the effect of training on the performance of the administrative staff of universities has not been adequately assessed by past related studies on the subject matter. Yamane (1967)'s formula $\left(n=N / 1+N\left(e^{2}\right)\right.$, where $n=$ Sample Size, N = Population of the Study, and e = error margin @ 5\% (0.05), was used to select 74 out of the 91 administrative staff. Copies of the structured questionnaire were administered to the 74 staff. However, only 68 (92\%) copies were retrieved. The copies of questionnaire were made up of two sections, A and B. Section A consisted of personal bio-data of the respondents while section B was made up of questions drawn to measure the effect of training on employees' performance of the administrative staff in the study area. Data for this study were analyzed using descriptive statistics - percentage, mean score, standard deviation, mean ranking, and chi-square $\left(\chi^{2}\right)$ was used to test the hypothesis posed for the research at $5 \%$ significant level. Validation of the research instrument was carried out by a senior lecturer in the Department of Business Administration in FUTA, while the Reliability test was carried out with Cronbach Alpha. The result of the reliability test on the research instrument used for the research work revealed a Cronbach's Alpha coefficient of 0.928 which is greater than 0.7. This indicated that the result is high and it is suitable for social science.

\subsection{Results and Discussions}

\subsection{Socio-economic Characteristics of Respondents}

Table 2 shows that 25\% of the respondents had 1- 5 years of experience, $26.5 \%$ had 6 - 10 years of experience, $27.9 \%$ had $11-15$ years, $14.7 \%$ had $16-20$ years, while $5.9 \%$ had above 20 years of experience. This shows that the staff had enough experience to give valuable information on the training they undertook.

The study also disclosed that 2.9\% had Ph. D., 44.1\% had M.Sc., and 50.0\% had B.Sc/HND, while 2.9\% had OND. This means that majority of the staff are literate who have enough intelligence to work in the study area, undergo training and give valid responses to the research questions that were asked. Furthermore, $5.9 \%$ of the respondents were between 20 and 29 years, $29.4 \%$ were between 30 and 39 years, $45.6 \%$ were between 40 and 49 years, $13.2 \%$ were between 50 and 59 years, while $5.9 \%$ were 60 years and above. This implies that a lot of the respondents were between 30 and 49 years. They are adults, who are within the productive age and can contribute to the development of the study area. Also, 100\% of the respondents were Nigerians. 


\subsection{Training Types mostly used for the Administrative staff in the Study Area}

Table 3 presents a summary of the training types mostly used for the administrative staff in the study area. The table disclosed that "On the Job" and "Off the Job" training methods are used almost equally, for training staff in the study area. Regarding on the Job training, Committee Assignment was ranked highest with means score of 3.75, followed by Understudy/Apprenticeship with mean score 3.19. The third and fourth on the rank were Job Rotation (mean score 2.99) and Coaching (mean score 2.34) respectively. While in respect of Off the Job training, Workshop was ranked highest with means score of 3.54, followed by Seminar with mean score 3.46. The third, fourth and fifth on the rank were, conference (mean score 3.40), Film Show and Demonstration (mean score 2.10) and Educational Television (mean score 2.01) respectively.

These findings are in line with those of Onyango and Wanyoike (2014) who stated that training is mainly imparted in two ways: on the job training which is made available to employees within their daily working environment and off the job training method which is made available to employees outside their working environment, for example, conferences, seminars, workshops, among others. However, the findings do not agree with that of Dilworth (2003), who maintained that classroom-based training or off-the-job training is decreasing as technology and other methods of training including on-the-job instruction, problem-based learning, mentorship, action learning, fieldwork visits and job rotation have become more predominant. Also, Sadler-Smith et al. (2000), Budhwar et al. (2002), Elbadri (2001), Garavan et al. (2002), among others, affirmed that On-the-job instruction training has been acclaimed to be more frequently used in firms. The findings in this study show that combinations of on the job training and off the job training methods were comparatively used in the study area.

Table 2: Distribution of Socio-economic Characteristics of Respondent

\begin{tabular}{llcc} 
Characteristic & Respondent Category & Frequency & Percentage (\%) \\
\hline YEARS OF & 1- 5 years & 17 & 25.0 \\
EXPERIENCE & & & 26.5 \\
& 6- 10 years & 18 & 27.9 \\
& 11- 15 years & 19 & 14.7 \\
& 16-20 years & 10 & 5.9 \\
& Above 20years & 4 & 100.0 \\
GENDER & TOTAL & 68 & 57.4 \\
\hline
\end{tabular}




\begin{tabular}{|c|c|c|c|}
\hline & Female & 29 & 42.6 \\
\hline & TOTAL & 68 & 100.0 \\
\hline \multirow[t]{3}{*}{ MARITAL STATUS } & Single & 6 & 8.8 \\
\hline & Married & 62 & 91.2 \\
\hline & TOTAL & 68 & 100.0 \\
\hline \multirow{5}{*}{$\begin{array}{l}\text { EDUCATIONAL } \\
\text { QUALIFICATION }\end{array}$} & Ph.D. and Others & 2 & 2.9 \\
\hline & M.Sc. & 30 & 44.1 \\
\hline & B.Sc./HND & 34 & 50.0 \\
\hline & OND & 2 & 2.9 \\
\hline & TOTAL & 68 & 100 \\
\hline \multirow[t]{6}{*}{ AGE } & $20-29$ & 4 & 5.9 \\
\hline & $30-39$ & 20 & 29.4 \\
\hline & $40-49$ & 31 & 45.6 \\
\hline & $50-59$ & 9 & 13.2 \\
\hline & 60 and Above & 4 & 5.9 \\
\hline & TOTAL & 68 & 100.0 \\
\hline \multirow[t]{3}{*}{ NATIONALITY } & Nigerian & 68 & 100.0 \\
\hline & Others & - & - \\
\hline & TOTAL & 68 & 100.0 \\
\hline $\begin{array}{l}\text { DIVISION AND } \\
\text { UNIT/DEPARTME } \\
\text { OF RESPONDENT }\end{array}$ & & UNIT/DEPARTMENT & \\
\hline \multirow[t]{8}{*}{ DIVISION } & $\begin{array}{c}\text { Directorate of } \\
\text { Establishment and } \\
\text { Human Resource } \\
\text { (DHR) }\end{array}$ & 8 & 11.8 \\
\hline & $\begin{array}{c}\text { Directorate of } \\
\text { Academic Affairs }\end{array}$ & 23 & 33.8 \\
\hline & Council & 5 & 7.4 \\
\hline & Registrar's Office & 4 & 5.9 \\
\hline & Student Affairs Office & 8 & 11.8 \\
\hline & School Admin & 20 & 29.4 \\
\hline & TOTAL & 68 & 100.0 \\
\hline & Training Unit & 2 & 2.9 \\
\hline \multirow[t]{7}{*}{ UNIT } & Welfare Unit & 2 & 2.9 \\
\hline & Junior Staff Unit & 2 & 2.9 \\
\hline & Academic Unit & 1 & 1.5 \\
\hline & Admin and & 1 & 1.5 \\
\hline & Professional Staff Unit & & \\
\hline & Senate & 2 & 2.9 \\
\hline & Admission & 2 & 2.9 \\
\hline
\end{tabular}




\begin{tabular}{lccc}
\hline & Examination and & 19 & 27.9 \\
Records & & 4.4 \\
& Council Affairs Unit & 3 & 2.9 \\
General Admin & 2 & 5.9 \\
Registrar's Office & 4 & \\
Officers & & 2.9 \\
& Student Affairs Office & 2 & 7.4 \\
Counselling Unit & 5 & 27.9 \\
& School Officers & 19 & 2.9 \\
& Admin Officers & 2 & 100.0 \\
Source: Field Work 2017 & TOTAL & 68 & \\
\hline
\end{tabular}

Table 3: Distribution of Training Types used for the Administrative staff in the Study Area

\begin{tabular}{llllllllll}
\hline S/N & Training Type & VL & L & M & H & VH & MEAN & MEAN \\
& & & & & & RANK
\end{tabular}

On the Job Method

1 Job Rotation

$\begin{array}{ccccccc}12(17.6 \%) & 14(20.6 \%) & 18(26.5 \%) & 9(13.2 \%) & 15(21.1 & 2.99 & 3 \\ & & & & & \\ 8(11.8 \%) & 4(5.9 \%) & 20(29.4 \%) & 7(10.3 \%) & 29(42.6 & 2.34 & 4 \\ & & & & & \end{array}$

3 Understudy/Apprenticeship

$16(23.5 \%) \quad 12(17.6 \%) \quad 20(29.6 \%) \quad 9(13.2 \%)$

$11(16.2 \quad 3.19 \quad 2$

4 Committee Assignment

$25(36.8 \%) \quad 21(30.9 \%) \quad 10(14.7 \%) \quad 4(5.9 \%)$

$\%)$

8

$3.75 \quad 1$

Off the Job Method

$5 \quad$ Film Show and Demonstration

$$
\begin{array}{lccccc}
6(8.8 \%) & 4(5.9 \%) & 12(17.6 \%) & 15(22.1 \%) & 23(33.8 & 2.10 \\
2((2.9 \%) & 8(11.8 \%) & 8(11.8 \%) & 21(30.9 \%) & 29(42.6 & \\
& & & & \\
& & & & \\
& & & &
\end{array}
$$

7 conferences

$15(22.1 \%) \quad 20(29.4 \%) \quad 14(20.6 \%) \quad 15(22.1 \%) \quad 4(5.9 \%) \quad 3.40$

8 Seminars

$14(20.6 \%) \quad 21(30.9 \%) \quad 18(26.5 \%) \quad 12(17.6 \%) \quad 3(4.4 \%) \quad 3.46$ 
Source: Field Work 2017

\subsection{Factors Affecting Effective Training of the Respondents in the Study Area}

Table 4 disclosed the factors that affect effective training of the respondents in the study area. Item 2 (Management's complaint about lack of fund for training) was ranked first with a mean score of 3.78 and a standard deviation of 1.183. Item 13 (Lack of incentives to attend training) was next on the rank with a mean score of 3.15 and standard deviation of 1.319 followed by item 8 (Believe by employees that they will not receive value from learnt skills, with a mean score of 2.53 and standard deviation of 1.298 . While the fourth item on the rank was item 1 (Unavailability of training programmes under my working conditions) with a mean score of 2.44 and a standard deviation of 1.226. These results are not far from those of Cascio (2005) and Kum et al., (2014) who identified insufficient resources as one of the factors that can thwart employees' training and development. Also, Kum et al., (2014) who identified working conditions as one of the factors that affect the training and development of employees. Similarly, the results are in agreement with those of Kreitner and Kinicki (2007) who stated that when learners do not see any value in applying new skills, do not believe that they will receive rewards from learnt skills, do not value the rewards that

will be attained from learning such skills, the outcome of such training may not be positive. Likewise, these results are in line with those of Perry (2007) and Kleiman (2003), who asserted that the failures of training and development programmes can be linked with failure of the training objectives to be affiliated with the business needs, and reward system.

However, item 12 (Coworkers are sceptical of receiving new ideas) was least ranked with a mean score of 2.10 and standard deviation of 1.010, followed by item 3 (Heads of units are not in favour of training) with a mean score of 2.15 and standard deviation of 1.149. While item 4 (Management is not in favour of training was the next least scored) with a mean score of 2.11 and standard deviation of 1.112, followed by item 6 (Non-encouragement of application of new skills by Heads of units) with a mean score of 2.18 and a standard deviation of 1.064 . This result implies that coworkers are receptive to new ideas and therefore support training and development in the study area. Also, management and heads of units are in support of training and application of new skills. 
Table 4: Distribution of Factors Affecting Effective Training of the Respondents in the Study Area

\begin{tabular}{|c|c|c|c|c|}
\hline $\mathbf{S} / \mathbf{N}$ & Factors & Mean & $\begin{array}{c}\text { Std. } \\
\text { Deviation }\end{array}$ & $\begin{array}{l}\text { Mean } \\
\text { Ranking }\end{array}$ \\
\hline 1 & $\begin{array}{l}\text { Unavailability of training programmes under my working } \\
\text { conditions }\end{array}$ & 2.44 & 1.226 & 4 \\
\hline 2 & Management's complaint about lack of fund for training & 3.78 & 1.183 & 1 \\
\hline 3 & Heads of units are not in favour of training & 2.15 & 1.149 & 11 \\
\hline 4 & Management is not in favour of training & 2.11 & 1.112 & 10 \\
\hline 4 & $\begin{array}{l}\text { Non-encouragement of application of new skills by } \\
\text { management. }\end{array}$ & 2.25 & .983 & 7 \\
\hline 5 & $\begin{array}{l}\text { Non-encouragement of application of new skills by Heads } \\
\text { of units. }\end{array}$ & 2.18 & 1.064 & 9 \\
\hline 6 & Nonchalant attitude of employees towards training & 2.41 & 1.307 & 5 \\
\hline 7 & $\begin{array}{l}\text { Believe by employees that they will not receive value from } \\
\text { learnt skills }\end{array}$ & 2.53 & 1.298 & 3 \\
\hline 8 & $\begin{array}{l}\text { Believe by employees that they will not receive rewards } \\
\text { from learnt skills }\end{array}$ & 2.38 & 1.172 & 6 \\
\hline 9 & $\begin{array}{l}\text { Believe that transfer of learning from the classroom to the } \\
\text { job will not take place }\end{array}$ & 2.24 & 1.094 & 8 \\
\hline 10 & $\begin{array}{l}\text { Believe that tight control over their job tasks will not allow } \\
\text { the learnt skill to be put to use }\end{array}$ & 2.24 & 1.024 & 8 \\
\hline 11 & Coworkers are sceptical at receiving new ideas & 2.10 & 1.010 & 12 \\
\hline 12 & Lack of incentives to attend training & 3.15 & 1.319 & 2 \\
\hline
\end{tabular}

Source: Field Work 2017

\subsection{Effect of Training on Respondents' Performance}

Table 5 presents the distribution of the effect of training on respondents' performance as rated by the respondents. Item 2 (Improved skills and competencies) was ranked highest with a mean score of 4.31, a standard deviation of $.935, \chi^{2}=67.147$ and $p$-Value $=.000$. Item 1 (Improved knowledge and attitude) was the next important item after item 2, with a mean score of 4.29, a standard deviation of $1.023, \chi^{2}=14.2$, 
and $p$-Value $=.000$. While items 4 and 23 (Improved quality of work and Increased ability to acquire and use Information respectively) are the third items on the rank with mean scores of 4.18 and 4.18, standard deviations of .945 and $.897, \chi^{2}=49.500$ and 26.588, and $p$-Values $=.000$ and .019 respectively. The chisquare test revealed that items 1, 2, 4 and 23's p-Values were significant. These results implied that training had a significant effect on the respondents' performance. These results are similar to those of Armstrong (2000), Harrison (2000), Naveed et al. (2014), Falola et al. (2014). and Nkosi (2015) who concluded that raining has a direct relationship with employees' performance. There is a positive correlation between effective training program and employee's productivity (Bartel, 1994). Also, (Kum et al. (2014) who affirmed that training makes available to employees, skills that increase their performance and Jagero et al. (2012) who opined that trained employees are more proficient in executing different tasks. Similarly, Kum et al. (2014) agreed that training can make employees become more loyal to the firm and improve their job satisfaction, while Armstrong (2000) affirmed that employees who are trained usually work better as teams since they are all cognizant of expectations from them, therefore, they can attain these expectations smoothly together.

Furthermore, the findings of this study are similar to those of Bartel (1994) and Delery and Doty (1996) who agreed that training results in an improvement in employee's performance and organizational productivity, Obisi (2001), Guest (1997), Peteraf (1993) and Oguntimehin (2001), who concluded that training and development programs affect the quality of the workers' attitude, competence, skills and knowledge and results in greater employees' performance. Also, Valle et al. (2000) asserted that effective training plays an essential role in building and maintaining competencies at the individual and organizational level, and hence partakes in the process of organizational change. Similarly, Usman (2014) confirmed that training assists firms to attain a competitive advantage by developing capabilities and particular skill sets, stimulating innovation and producing new knowledge. While Tai (2006) disclosed that training aids in building a more favourable learning environment for employees and train them to cope with future challenges more easily and on time. Likewise, Wright and Geroy (2001) concluded that effective training programs help to change employees' competencies, ability to perform their current jobs effectively improves their skills, knowledge, attitude necessary for the employees to perform future jobs, consequently it increases employees' overall performance. While Analoui (1994) concluded that a suitable amount of training and development results to increased employee's knowledge, loyalty and productivity to the organization. On the other hand, Robbins et al. (2003) concluded that a lot of employers oppose training and development programmes in their firms because they feel that the responsibility to train employees falls on the school system, not on firms. Therefore, training is the duty of the employees. Employees 
should learn how to do their jobs so that they can be hired. They, therefore, regarded training and development programme as an expense which is difficult to convince shareholders to approve.

However, item 15 (Less absenteeism) was the lowest ranked item on the list, with mean score of 3.56, standard deviation of 1.013, $\chi^{2}=37.29$ and $p$-Value $=.000$, followed by item 16 (Improved job security) with mean score of 3.62, standard deviation of $.978, \chi^{2}=32.588$ and $p$-Value $=.000$. The next on the least rank was item 14 (Fewer accidents) with a mean score of 3.75, a standard deviation of $1.056, \chi^{2}=24.206$ and $p$-Value $=.000$. However, the chi-square test revealed that items 15,16 and 14 's p-Values were also significant. In summary, training of the respondents significantly improved the respondents' skills, competencies, knowledge, attitude, quality of work, ability to acquire and use information, among others. However, although less absenteeism, improved job security and fewer accidents were the least ranked items, their mean scores were still high (over 3.00). This implies that training of the respondents in total had a significant effect on the respondents' performance. Nevertheless, unlike the findings of Oguntimehin (2001) less absenteeism was scored lower than most factors that training affects in the study area, while unlike Cascio (2005)'s submission that job security is one of the main reasons why employees need training was also scored lower than other factors in this study.

Table 5: Distribution of the Effect of Training on Respondents' Performance

\begin{tabular}{|c|c|c|c|c|c|c|c|}
\hline $\mathbf{S} / \mathbf{N}$ & EFFECT & Mean & $\begin{array}{c}\text { Std. } \\
\text { Deviation }\end{array}$ & $\begin{array}{l}\text { Mean } \\
\text { Ranking }\end{array}$ & $\begin{array}{c}\text { (Chi-Square) } \\
\mathbf{X}_{2}\end{array}$ & df & $\begin{array}{c}P \text { - } \\
\text { Value }\end{array}$ \\
\hline 1 & Improved knowledge and Attitude & 4.29 & 1.023 & 2 & $72.000^{a}$ & 4 & .000 \\
\hline 2 & Improved skills and Competences & 4.31 & .935 & 1 & $67.147^{\mathrm{a}}$ & 4 & .000 \\
\hline 3 & Improved Motivation & 4.15 & .851 & 5 & $23.765^{\mathrm{b}}$ & 3 & .000 \\
\hline 4 & Improved quality of work & 4.18 & .945 & 3 & $49.500^{a}$ & 4 & .000 \\
\hline 5 & Improved morale & 4.07 & 1.069 & 8 & $41.265^{\mathrm{a}}$ & 4 & .000 \\
\hline 6 & Improved confidence & 4.15 & .935 & 5 & $22.941^{\mathrm{a}}$ & 3 & .000 \\
\hline 7 & Improved my thinking ability & 4.15 & .950 & 5 & $23.765^{\mathrm{a}}$ & 3 & .000 \\
\hline 8 & Improved my creativity & 4.03 & .992 & 10 & $15.294^{b}$ & 3 & .002 \\
\hline 9 & Improved my ability to use modern technology & 4.07 & 1.027 & 8 & $20.824^{a}$ & 3 & .000 \\
\hline 10 & More independent in carrying out my duties & 4.03 & 1.065 & 10 & $37.147^{\mathrm{a}}$ & 4 & .000 \\
\hline 11 & Better in Decision Making & 4.16 & .822 & 4 & $26.471^{\mathrm{a}}$ & 3 & .000 \\
\hline
\end{tabular}




\begin{tabular}{|c|c|c|c|c|c|c|c|}
\hline 12 & Improved Job Security & 3.90 & .849 & 12 & $18.706^{\mathrm{a}}$ & 3 & .000 \\
\hline 13 & Improved Job Satisfaction. & 3.87 & 1.064 & 13 & $28.912^{\mathrm{b}}$ & 4 & .000 \\
\hline 14 & Less Absenteeism & 3.75 & 1.056 & 15 & $24.206^{a}$ & 4 & .000 \\
\hline 10 & Fewer Accidents & 3.56 & 1.013 & 18 & $37.294^{\mathrm{a}}$ & 4 & .000 \\
\hline 16 & Less Mistakes & 3.74 & .956 & 16 & $36.118^{a}$ & 3 & .000 \\
\hline 17 & Less Wastage of Time & 3.62 & .978 & 17 & $32.588^{\mathrm{a}}$ & 4 & .000 \\
\hline 18 & Less Wastage of Materials & 3.79 & 1.030 & 14 & $30.824^{b}$ & 4 & .000 \\
\hline 19 & Increased Productivity & 4.00 & 1.184 & 11 & $37.735^{\mathrm{a}}$ & 4 & .000 \\
\hline 20 & Improved Efficiency & 4.16 & .987 & 4 & $28.353^{\mathrm{a}}$ & 4 & .000 \\
\hline 21 & More confidence in performance & 4.04 & 1.057 & 9 & $38.324^{a}$ & 4 & .000 \\
\hline 22 & Increased ability to generate new ideas & 4.03 & 1.079 & 10 & $37.882^{\mathrm{a}}$ & 4 & .000 \\
\hline 23 & Increased ability to accept change & 3.93 & 1.027 & & $10.000^{\mathrm{b}}$ & 3 & .019 \\
\hline 24 & Increased ability to acquire and use Information & 4.18 & .897 & 3 & $26.588^{a}$ & 3 & .000 \\
\hline 25 & $\begin{array}{l}\text { Increased ability to work without close } \\
\text { supervision }\end{array}$ & 4.12 & .856 & 7 & $22.235^{\mathrm{a}}$ & 3 & .000 \\
\hline 26 & More loyal to my work & 4.15 & .966 & 5 & $36.118^{\mathrm{a}}$ & 3 & .000 \\
\hline 27 & More commitment towards my Work & 4.13 & .976 & 6 & $25.294^{\mathrm{a}}$ & 3 & .000 \\
\hline
\end{tabular}

Source: Field Work 2017

\section{Conclusion}

The study revealed that a combination of "On the Job" training and "Off the Job" training were the most frequently used methods of training staff in the study area. The study disclosed that the factors that most affected effective training of the respondents were management's complaint about lack of funds for training and lack of incentives to attend training. The implication of this is that staff may find it difficult to adapt to changes that may occur as a result of changes that may take place in the working environment, due to lack of training. This would put them at a disadvantaged position among their colleagues in institutions of learning in other parts of the world and also affect their level of competence, efficiency and effectiveness. In the long run, this would have an adverse effect on the attainment of the goal of the institution. In addition, the study revealed that the Heads of units and management are receptive to new ideas and support training and development of the staff in the study area, however, they are hindered by inadequate capital allocated to the institution by the Government. The findings of the study also revealed that training improved the member of staff' skills, competencies, knowledge, attitude, quality of work and increased their ability to acquire and use information. The study, therefore, concluded that training had a significant effect on the 
performance of the academic staff in the study area. However, the Government needs to release adequate funds to the institution, while the management of the institution needs to release enough funds towards adequate training of the administrative staff, in order to enable continuous training of staff on current skills and methods rather than depending on obsolete, inefficient and retrogressive skills that are detrimental to the attainment of the institutional goal, and make the staff less competitive compared to their colleagues in other parts of the world. 


\section{References}

1. Afaq, F., U. and Khan, A., (2008), Case of Pearl Continental hotels in Pakistan, Relationship of training with Employees' Performance in Hoteling Industry.

2. Amin, A., Saeed, R., Lodhi, R. N., Simra, M., Iqbal, A and Tehreem, R., (2013), The Impact of Employees' Training on the Job Performance in Education Sector of Pakistan, Middle-East Journal of Scientific Research, 17 (9): 1273-1278.

3. Armstrong, M., (2010), A Handbook of Human Resource Management Practice, (11th ed.). Kogan Page Limited.

4. Armstrong, M., (2010), A Handbook of Performance Management, $4^{\text {th }}$ edition, New Delhi: Kogan Page Limited London.

5. Analoui, F., (1994), Training and Development: The Role of Trainers, Journal of Management Development, 13(9): 61-72.

6. Arnoff, J., (1971), Achievement Motivations Training and Executives Advancement, Journal of Applied Science, 7(1).

7. Banjoko, S. A., (1996), Human Resources Management An expository Approach.

8. Bartel, A. P., (1994), Productivity Gains for the Implementation of Employee Training Programs, Industrial Relations, 33(4): 411-428.

9. Becker, G. S., (1993), Human Capital: A Theoretical and Empirical Analysis with Special Reference to Education, $3^{\text {rd }}$ ed., Chicago, IL: University of Chicago Press.

10. Becker, G. S., (1975), Human Capital, New York: Columbia University Press.

11. Budhwar, P. S., Al-Yahmadi, S. and Debrah, Y., (2002), Human Resource Development in the Sultanate of Oman, International Journal of Training and Development, 6(3): 198.

12. Cascio, W. F., (2005), Managing human resources, (4th Ed), London: McGraw-Hill: 342.

13. Chen, T. Y, Chang, P. L. and Yeh, C. W., (2004), A study of Career Needs, Career Development Programs, Job Satisfaction and the Turnover Intensity of R \& D Personnel, Career Development International, 9(4): 424-437.

14. Chiaburu, D. S. and Tekleab, A. G., (2005), Individual and Contextual Influences on Multiple Dimensions of Training Effectiveness, Journal of European Industrial Training, 29(8): 604-626.

15. Colarelli, S. M. and Montei, M. S., (1996), Some Contextual Influences on Training Utilization, Journal of Applied Behavioral Science, 32(3): 306-322.

16. Delaney, J. T. and Huselid, M. A., (1996), The Impact of Human Resource Management Practices on perceptions of organizational performance, Academy of Management Joumal, 39(4): 949-969. 
17. Delery, J. E. and Doty, D. H., (1996), Modes of Theorizing in Strategic Human Resource Management: Tests of Universalistic, Contingency and Configurational Performance Predictions, Academy of Management Journal, 39(4): 802-835.

18. Deming, W. E., (1982), Quality, Productivity and Competitive Position, MIT Center for Advanced Engineering, Cambridge, MA.

19. Dilworth, L., (2003), Searching for the Future of HRD, Advances in Developing Human Resources, 5(3): 241-244.

20. Elbadri, A. N. A., (2001), Training Practices of Polish Companies: An Appraisal and Agenda for Improvement, Journal of European Industrial Training, 25(2-4):69-79

21. Elnaga1, A. and Imran, A., (2013), The Effect of Training on Employee Performance, European Journal of Business and Management, 5(4): 137-145. www.iiste.org.

22. Evans, J. R. and Lindsay W. M., (1999), The Management and Control of Quality, $4^{\text {th }}$ edition, Cincinnati Ohio: South-Western College Publishing.

23. Falola, H. O., Osibanjo, A. O. and Ojo, S. I., (2014), Effectiveness of Training and Development on Employees' Performance and Organisation Competitiveness in the Nigerian Banking Industry. In Bulletin of the Transilvania University of Braşov.

24. Flynn, B. B., Schroeder, R.G. and Sakakibara, S., (1995), The Impact of Quality Management Practices on Performance and Competitive Advantage, Decision Sciences, 26: 659-691.

25. Frost, T., Vos, S. and Dreyer, J., (2000), Organizational Development, Mumbai: Jaico Publishing.

26. Garavan, T. N., Morley, M., Gunnigle, P. and McGuire, D., (2002), Human Resource Development and Workplace Learning: Emerging Theoretical Perspectives and Organizational Practices, Journal of European Industrial Training, 26(2-4): 60-71.

27. Ginsberg, L., (1997), Training for the Long Haul, Computer Shopper, 17: 04. In Griffin, A. M. and Neal, A., (2000), Perceptions of Safety at Work: A Framework for Linking Safety Climate to Safety Performance, Knowledge, and Motivation, Journal of Occupational Health Psychology, 05(03): 347-358.

28. Grobler, P., Warnich, S., Carrell, R., Elbert, F. and Hartfield, D., (2004), Human Resource Management in South Africa, $\beta^{\text {rd }}$ Ed), UK: Thomson Learning: 123, 130.

29. Guest, D., (1997), Human Resource Management and Performance: A Review and Research Agenda, International Journal of Human Resource Management, 8(3): 263-276.

30. Goldstein, I. L., (1993), Training in Organization: Needs Assessment, Development and Evaluation, (3rd ed.), California: Brooks/Cole Publishing Co.

31. Harrison, R., (2000), Employee Development, Silver Lakes, Pretoria: Beekman Publishing.

32. Jagero, N., Komba, H. V. and Mlingi, M. D., (2012), Relationship Between on the Job Training and Employee's Performance in Courier Companies in Dar es Salaam, Tanzania, International Journal of Humanities and Social Science, 2(22): 114-120. 
33. Junevicius, A. and Seniunaite, I., (2007), The Role of Individual Performance for Effective Public Management: European Union and Lithuanian Case Studies, European Integration Studies, 1: 3536.

34. Katcher, S. and Snyder, T., (2003), Organisational Commitment, USA: Atomic Dog: 90.

35. Khan, R. A. G., Khan, F. A. and Khan, M. A., (2011), Impact of Training and Development on Organizational Performance, Global Journal of Management and Business Research, 11(7): 63-68.

36. Kleiman, L. S., (2003), Human Resource Management, (3rd Ed), USA: Atomic Dog: 49- 389.

37. Kreitner, R. and Kinicki, A., (2007), Organisational Behaviour, (7th Ed), New York: McGraw Hill/Irwin: 69.

38. Kum, F. D., Cowden, R. and Karodia, A. M., (2014), The Impact of Training and Development on Employee Performance: A Case Study of Escon Consulting, Singaporean Journal of Business Economics and Management Studies, 3(3): 72-105.

39. McConnelll, R. C., (2004), Managing Employee Performance. Journal of Health Care Management, 23(3): 239, 273-283.

40. Naveed, A., Iqbal, N., Mir, M. S., Haider, Z. and Hamad, N., (2014), Impact of Training and Development on the Employee Performance: "A Case Study from Different Banking Sectors of North Punjab, Arabian Journal of Business and Management Review (Nigerian Chapter), 2(4): 1924.

41. Nel, P., Gerber, P., Van Dyk, P., Haasbroek, D., Schultz, H., Sono, T. and Werner, A., (2004), Human Resources Management, (6th Ed), South Africa: Oxford University Press: 142, 145, 167.

42. Nkosi, S. M., (2015), Effects of Training on Employee Commitment, Retention and Performance: A Case Study of a Local Municipality in South Africa, European Journal of Business and Management, 7(15): 104-108. www.iiste.org.

43. Noe, A. R., Hollenbeck, R. J., Gerhart, B. and Wright, P. M., (2003), Human Resource Management, (3rd Ed), USA: McGraw-Hill: 51, 251, 379, 391.

44. Noe, R. A., Hollenbeck, J. R., Gerhart, B. and Wright, P. M., (2006), Human Resource Management, (5th Ed), New York: McGraw-Hill.

45. Noor, K. B. M. and Dola, K., (2011), Investigating Training Impact on Farmers' Perception and Performance, International Journal of Humanities and Social Science, 1(6): 145-152.

46. Obisi, C., (2001), Employee Development, Issues and Dimensions, Unical Journal of public Administrator, Vol. 1.

47. Ostroff, C. and Bowen, D. I., (2000), Moving HR to a Higher Level Human Resource Practices and Organizational Effectiveness. In K. J. Klein and S. W. J. Kozlowski (Eds.) Multilevel Theory, Research and Methods in Organizations, San Francisco: Joossey-Bass: 211-266. 
48. Oguntimehin, A., (2001), Teachers' Effectiveness: Some Practical Strategies for Successful Implementation of Universal Basic Education in Nigeria, African Journal of Education Management, 9(1): 151-161.

49. Ohabunwa, S., (1999), Nigeria Business Environment in the New Millennium- Paper presented for HRDB UNILAG on Renovating our Corporate Management Practices for the New Millenium. Wednesday, 19th May, 1999.

50. Onyango, J. W. and Wanyoike, D. M., (2014), Effects of Training on Employee Performance: A Survey of Health Workers in Siaya County, Kenya. European Journal of Material Sciences, 1(1): 11-16. (www.ea-journals.org).

51. Oribabor, P. E. (2000). Human Resources Management, a Strategic Approval. Human Resources Management. Vol. 9(4). pp. 21 - 24.

52. Perry, B., (2007), Organizational Management and Information Systems, Oxford: Elsevier: 95, 282.

53. Peteraf, M. A., (1993), The Cornerstones of Competitive Advantage: A Resource-Based View, Strategic Management Journal, 14(3):179-192.

54. Pfeffer, J., (1994), Competitive Advantage through People, Boston, MA: Harvard Business School Press.

55. Reed, J. and Vakola, M., (2006), What Role can a Training need Analysis Play in Organizational Change?, Journal of Organizational Change Management, 19(3): 393-407.

56. Robbins, S. P., Odendaal, A. and Roodt, G., (2003), Organizational Behavior: Global and Southern African perspectives, South Africa: Pearson Education:157, 231, 401.

57. Roberson, L., Culik, C. T. and Pepper, M. B., (2001), Designing Effective Diversity Training: Influence of Group Composition and Trainee Experience, Journal of Organizational Behavior, 22(8): 871-885.

58. Rothwell, W. J. and Kazanas, H. C., (2006), Planning and Managing Human Resources, (2nd Ed), Mumbai: Jaico: 212, 234.

59. Sadler-Smith, E., Down, S., and Lean, J., (2000), Modern Learning Methods: Rhetoric and Reality, Personnel Review, 29(4): 474-490.

60. Schonewille, M., (2001), Does Training Generally Work? Explaining Labor Productivity Effects from Schooling and Training, International Journal of Manpower, 22(1/2): 158-173.

61. Shaw, J. D., Delery, J. E., Jenkins, G. D. and Gupta, N., (1998), An Organization-Level Analysis of Voluntary and Involuntary Turnover, Academy of Management Journal, 41(5): 511-25.

62. Smit, P. J. and de Cronje, G. J., (2003), Management principles, South Africa: Juta: 73, 78

63. Stone, R. J., (2002), Human Resource Management, 2nd Edition, USA: Jhon Wiley and Sons. 
64. Swart, J., Mann, C., Brown, S. and Price, A., (2005), Human Resource Development: Strategy and Tactics, Oxford: Elsevier Butterworth-Heinemann Publications.

65. Tai, W. T., (2006), Effects of Training Framing, General Self-efficacy and Training Motivation on Trainees' Training Effectiveness. Emerald Group Publishers, 35(1): 51-65.

66. Thomas, N. G., (1997), Interpersonal Skills Training for Quality Service Interactions, Industrial and Commercial Training, 29 (3): 70-77.

67. Usman, O. S., (2014), Assessment of Training and Development and its Effect on Employees' Job Performance in Yaba College of Technology, Yaba, Nigeria, Afro Asian Journal of Social Sciences, 5(5): $1-18$.

68. Valle, R., Martı' n, F., Romero, P. M. and Dolan, S., (2000), Business Strategy, Work Processes and Human Resource Training: are they Congruent?, Journal of Organizational Behavior, 21: 283-297.

69. Wright, P. and Geroy, D. G., (2001), Changing the Mindset: the Training Myth and the need for Word-Class Performance, International Journal of Human Resource Management, 12(4): 586-600.

70. Yamane, Y., (1967), Statistics: An Introductory Analysis, 2nd Ed. New York: Harper and Row.

71. Youndt, M. A., Snell, S. A., Dean, J. W. and Lepak, D. P., (1996), Human Resource Management, Manufacturing Strategy and Firm Performance, Academy of Management Journal, 39(4): 836-866. 